\title{
Grain size, composition, porosity and permeability contrasts within cross-bedded sandstones in Tertiary fluvial de posits, central Spain
}

\author{
CHRISTEL A. HARTKAMP、* JOSE ARRIBAS† and AMPARO TORTOSA† \\ * Foculty of Mining and Petroleum Engineering, Delfi University of Technology, P O Box 5028, 2600 GA Delfi. \\ the Netherlonds \\ +Departamento de Pearolugia y Geoguimica, Facultad de Ciencias Geologicas, Unicersidad Complusense. \\ 28040) Modriel. Spoin
}

\begin{abstract}
Permeability measured wit ha portable probe permeameter on outcrops of cross-bedded sandstones ranges between 0.9 and $19 \mathrm{D}$. The highest permeability (2-19 D with an a verage of $8.5 \mathrm{D}$ ) occurs in the coarsesi grained foreset laminae (CFL). intermediate values (2-12 with an a verage of 5.3 D) occur in finer grained foreset laminae (FFL) and the lowest values (0.9-10 D with an a verage of $4.8 \mathrm{D}$ ) occur in bottomset layers $(\mathrm{BL})$. In the cross-beds the a verage grain sizc ranges from medium grained sand in the CFL to fine grained sand in the FFL and $8 \mathrm{~L}$. In all three subfacies, the average size of the primary pores is approximately I $\phi$ unit smaller than the a verage grain size. The abundance of unstable carbonate clasts correlates with increasing a verage grain size, micritic clasts being most abundant in the CFL. Conversely, quartz content increases with decreasing grain size and is highest in the FFL and BL. Diagenetic destruction of primaty porosity by compaction and cementation, as well as generation of secondary porosity through dissolution, were controlled by the original mineralogical composition of the sand. Contrasts in grain size determine the primary pore size contrasts and differences in composition between CFL. FFL and $\mathbf{B L}$. Permeability conirasts reflect variations in a verage primary pore size rather than diflerences in total porosity. Probe permeability contrasts between CFL. FFL and $8 \mathrm{~L}$ depend on contrasts in :iverage pore size and contrasts in mineralogical composition between the subfacies.
\end{abstract}

\section{INTRODUCTION}

Many studies have related permeability measured by a probe permeameter at outcrop to the sampled sedimentary facies (e.g. Chandler et ol., 1989; Dreyer et al., 1990; Hartkamp \& Donselaar, 199.3). Most studies have concentrated on permeability variations on genetic-unit scale. In a laboratory setting, probe permeameter measurements can be made on a very fine-scale grid, enabling statistically valid comparisons to be made between the permeability distributions of individual laminae in cross-stratified units (grid point spacing of $5 \mathrm{~mm}$; Hurst \& Rosvoll, 1991). However, there are few studies that directly combine detailed probe permeametry at outcrop with microscopic textural and mineralogical observations.

In the past few decades, experimental, theoretical and semi-empirical relations have been established between pore and textural characteristics (e.g. grain size, sorting, specific surf ace of grains) of sands and sandstones with permeability (e.g. Kozeny, 1927 : Carman, 1937; Beard \& Weyl, 1973; van Baaren, 1979). Textural properties are basically determined by the primary mineralogical composition and the physical processes of sedimentation, but may be affected by subsequent burial history (e.g. physical compaction, mineralogical alteration and cementation; Pittman, 1979). Studies on reservoir sandstones have provided a more detailed insight into the dependence of permeability on porosity alteration as a result of diagenesis. For example. Ehrenberg (1990) studied North Sea reservoir sandstones and found that both finer grain size and higher mica content were associated with lower permeability. Differences in 
mineralogical composition between laminae within cross-stratified reservoir sandstones have been observed by Hopkins et ol. (1991)

permeability contrast of one order of magnitude between the laminae. Hurst \& Rosvoll (1991) determined a permeability contrast of $1-3$ orders of magnitude between laminae within a cross-bed of shallow marine origin in a lightly consolidated sandstone: they assumed that the variations in permeability reflected primary depositional characteristics

The present study focuses on quantification of permeability variations in cross-bedded sandstones.

The purpose of this paper is to document the depositional characteristics that affect contrasts in permeability between adjacent foreset laminae and between foreset and bottomset of cross-beds in well exposed distal fluvial fan deposits of Late Oligocene to Early Miocene age(Loranca $B$ asin in central Spain). Probe permeameter measurements are compared with textural and compositional parameters. The studied sand bodies are lightly consolidated and have retained most of their primary depositional features (Diaz Molina et al., 1989).

\section{GEOLOGICAL SETTING AND FACIES DESCRIPTION}

Sandstones of Middle to Late Tertiary age in the Loranca Basin of central Spain provide the data for this study (Fig. 1). Fluvial, molasse-type, sandstones from two coalescing systems filled the Loranca depression during the LateOligocene to Early Miocene (Diaz Molina et ol., 1989). The source areas of these fluvial sediments are the Mesozoic clastic and carbonate sequences of the Iberian mountain range. Channel sandbodies were formed by low and high sinuosity rivers and enclosed in fine grained floodplain sediments. Large scale troughcross-bedding is ubiquitous (Dia \% Molina et ol., 1985).

The trough cross-bedded sedimentary structures were formed by large scale ripple migration over the channel floor and the depositional slope of the inner bank. The trough cross-beds have lengths of up to 20) $\mathrm{m}$, thicknesses of $20-40 \mathrm{~cm}$ and widths of $80 \mathrm{~cm}$ to $2 \mathrm{~cm}$. Two different facies are distinguished: the bottomset and the foreset. The bottomset layer (BL) has formed in front of migrating ripples and consists of fall-out and suspension-load sediment. Foreset deposits consist of laminae that formed by grains at valanching down the leeside of ripples. The inclined foreset laminae are preserved in sequence in the sandbodies and are a record of successively earlier positions of the leesides. The grains are sorted during avalanching, resulting in distinct coarse (CFL) and

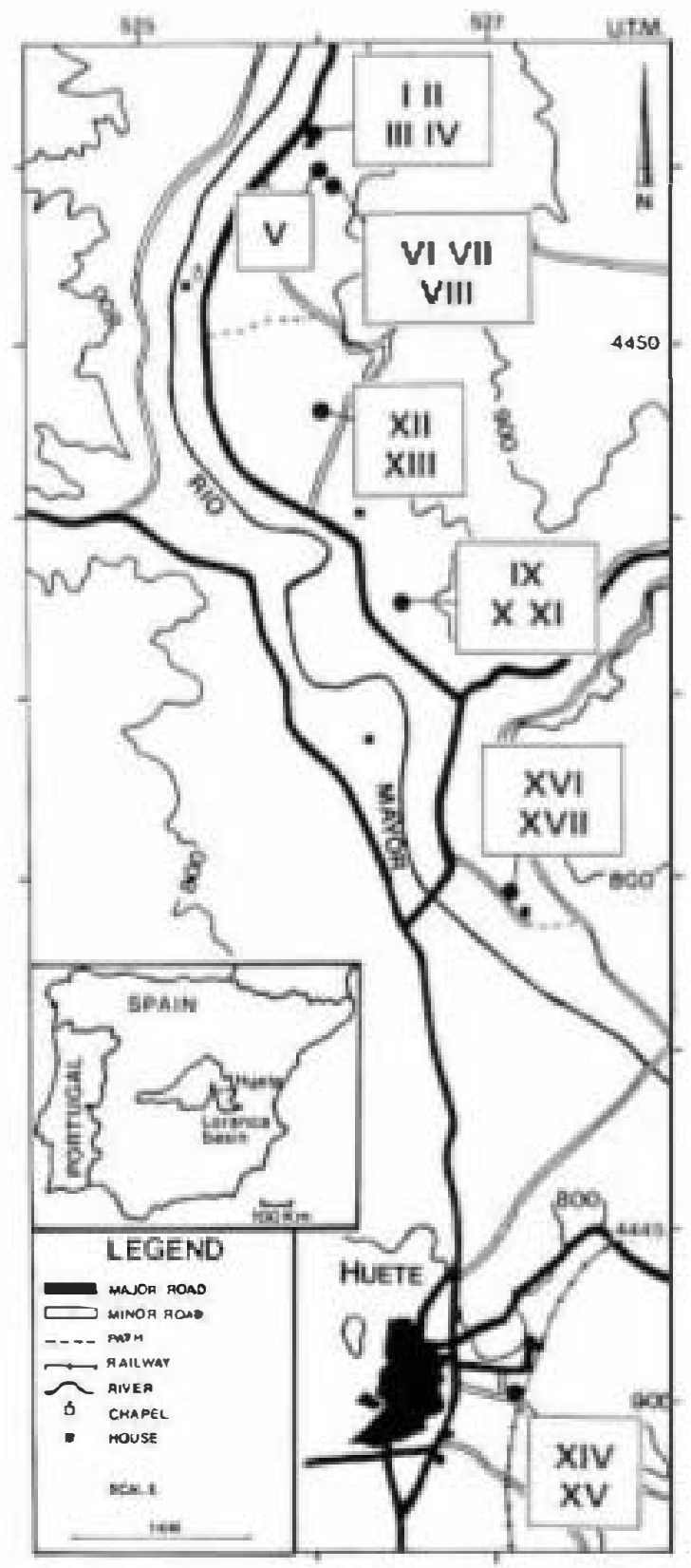

Fig. 1. Location map of the study area in the Loranca Basin of ccntral Spain. Studied outcrop locations are marked from I-X VII. 
fine grained (FFL) laminae that range between $2 \mathrm{~mm}$ and $1.2 \mathrm{~cm}$ in thickness. Usually, there is a regular and systematic pattern of variation in medium grain size with respect to the successive cross-strata.

\section{METHODOLOGY}

\section{Petrography}

A total of 34 plugs, each 2 in $(5.08 \mathrm{~cm})$ in diameter, were taken perpendicular to bedding from 17 outcrop locations (Figs 1 and $2 \mathrm{~A}-\mathrm{C}$ ). Probe permeability measurements were taken prior to coring and this technique provided us with undisturbed plugs of which the measured locations, orientations, exact sedimentologicaldetails, and probe permeability data were known at $90^{\circ}$ to layering. Thin sections of the plugs were made following impregnation with blue Araldite and a qualitative evaluation was made (Fig. 2C., D), and nine thin sections were selected and used for optical petrographical analysis. In each thin section, the coarser grained foreset laminae (CFL), the finer grained foreset laminae (FFL) and the bottomset layer (BL), if present were studied separately. The parameters studied comprise mineralogical composition, grain size distribution and porosity.

Petrographical analysis involved counting a total of 3300 points in each plug sample. For each subfacies (CFL, FFL and $\mathrm{BL}$ ), 400 points were counted of framework and cement type, 400 points were counted of pore type and size and a further 300 points were counted for grain size determination. In foreset laminae the point count parameters were counted parallel to the dip (Fig. 2D). In bottomsets the parameters were counted perpendicular to the depositional surface, to account for any anisotropy in texture that may be apparent in bottomsets (Joplin. 1965). In some samples, bottomsets display well developed, fine and coarse grained laminae: in these samples point counting was done parallel to the depositional surface in order to count coarse and fine grained laminae separately ( $\mathrm{BL}-\mathrm{C}$ and $\mathrm{BL}-\mathrm{F}$ ).

Maximum diameters of pore size and grain size were counted in $\phi$ unit intervals $\left(-\log _{2}\right.$ of the diameter (mm), Pettijohn et cl.. 1973). Mean values of grain size or pore size were used in the correlations with permeability. Sorting ( $S o=\phi$ standard deviation) was calculated in accordance with Folk (1980). Framework composition was analysed in petrographical groups as defined by Zuffa analysis (primary and secondary porosity) was carried out on the basis of the criteria defined by Schmidt \& McDonald (1979).

\section{Permeability}

The probe permeameter (minipermeameter) was developed for measuring the steady state permeability of rock and unconsolidated sand by Eijpe \& Weber (1971). Sutherland et al. (1991) recommended codes of practice that are applicable to the variety of instruments currently available and given details of the measurement principles, apparatus, measurement procedure and quality control for probe permeametry. The apparatus and the measurement techniques used for this study are described in detail by Hartkamp \& Donselaar (1993) and are only summarised here. The probe permeameter consist of three units, a nitrogen gas source, a flow meter unit and a probe. The probe is pressed against the rock surface with a controlled force (Sutherland et al. . 1991). Al at constant pressure, nitrogen is passed through a small opening in the probe into the rock and the flow rate is recorded when a steady state is reached (after $10 \mathrm{~s}$ ). Leakage between the rock and the probe is prevented by an elastic. closed-cell neoprene rubber. The inlet opening of the probe (radius of I mm) determines the measured rock volume (Goggin et al., 1988), which is estimated to have a radius and depth of $4 \mathrm{~mm}$. Where the thickness of laminae is less than the measurement radius, the measured permeability is an average value defined by the unknown permeabilities of more than one lamina (Halvorsen \& Hurst, 1990).

Flow rate is converted into permeability using a calibration curve (Fig. 3). This calibration curve was established in the Dietz laboratoryof Delft University of Technology (the Netherlands) using a set of 99 natural and artificial homogeneous sandstone plugs. the permeabilities of which ranged from 0.1 to $14000 \mathrm{mD}$. An extensivedescription of the principles, calibration, response, reliability and accuracy of the equipment used for this study is presented by Hartkamp (1993)

The outcrop face was carefully prepared using a steel brush to remove the superficial weathering crust and, subsequently, using a soft brush to remove the first few centimetres of the friable sandstone underneath the crust in order to remove dust and flatten the surface.

A total of 2600 measurements were made on crossbeds at 17 outcrop locations and statistically analysed. 


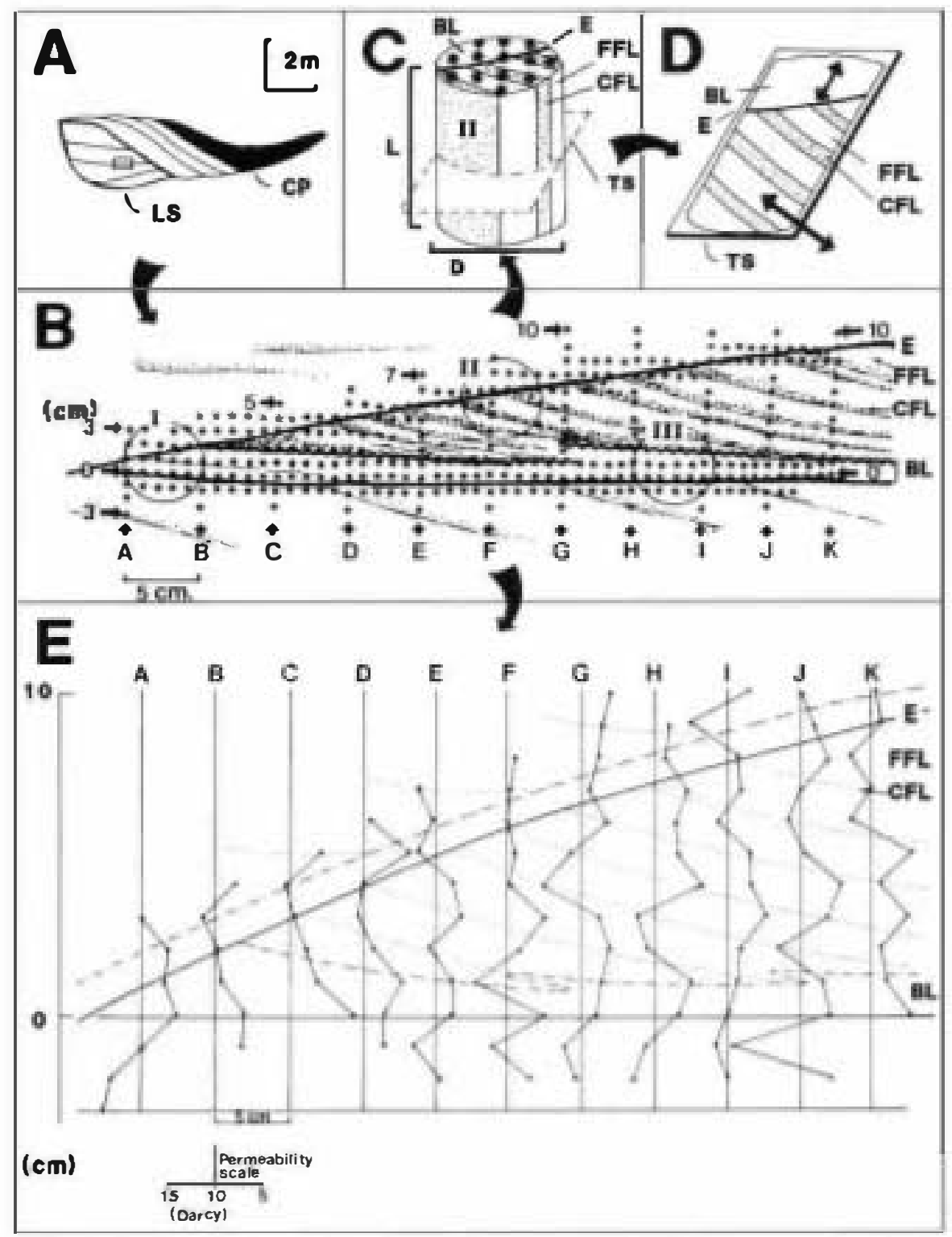

Fig. 2. ( $\Lambda) \wedge$ schematic cross-section of a laterally stacked sequence of adjacent point bar deposits (LS) and channel abandonment deposits represented by a clay plug (CP). Outcrop sample location VI is indicated by the rectangular box. (B) Drawing of the sampled cross-bed set of location VI. Coarser grained foreset laminate (CFL) are stippled, finer grained foreset laminae (FFL) are unornamented and the bottomset layer $(\mathrm{BL})$ is the unornamented zone parallel to the bold erosion surlace (E) and the undulating line. Circles indicate core plug locations (I. II and III). The grid used for probe permeameter measurements is indicated by asterisks (vertical grid spacing is $1 \mathrm{~cm}$. holizontal grid spacing between columns $\Lambda$ and $K$ is $5 \mathrm{~cm}$, with additional grid points $1 \mathrm{~cm}$ a part. (C) Example of core plug II with a length $(L)$ of $6 \mathrm{~cm}$ and a diameter (D) of $5.08 \mathrm{~cm}$. Inclined foreset laminate are presented as CFL (stippled) and FFL (unomamented). BL is unornamented and overlies the erosion surface (E). Asterisks indicate probe permeameter sample points. TS is the imaginarycross-section for the thin section. (D) Example ol thin section (TS) with foreset laminae CFL (stippled) and FFL (unornamented), the erosion surface (E) and overlying bottomset (BL). Arrows indicate the point count directions in the foreset (CFL. FFL) and in the bottomset (BL). (E) Example of permeability pattern of ou tcrop location VI; the dotted lines indicate inclined loreset laminae directions (CFI, FFL), the dashed line indicates the boundaty between forest and boltomset (BL) and the black line indicates the erosion surface (F.). 


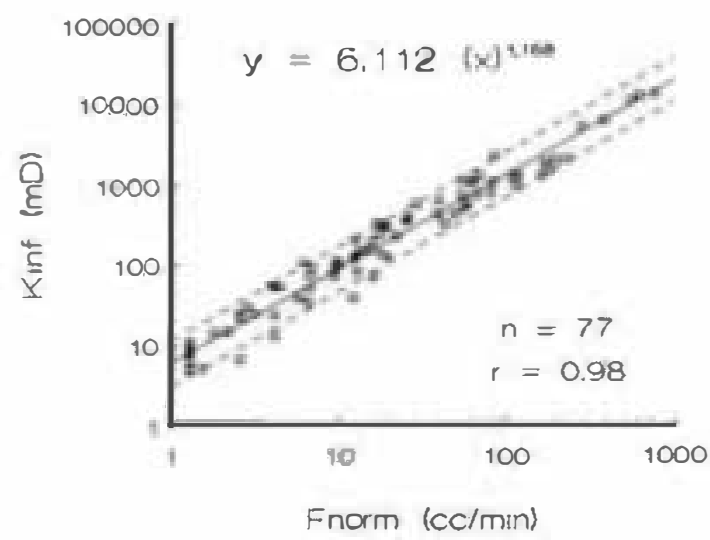

- Geom mean

Fig. 3. Calibration graph of the normalized flow rate $\left(F_{\text {nerm }}\right)$ measured by probe permeameter versus the infinite plug permeability $\left(\boldsymbol{K}_{\text {inr }}\right)$ (Hassler-sleeve) for the highest range in permeability (5 to $14000 \mathrm{mD}$ ). Data represent geometrical averages of four probe measurements taken at each end side of a core plug. The power regression relationship of the bestfit correlation (continuous line) is presented, together with the totainumber $(n)$ of core plugsinvolved and the correlation coefficient $(r)$. The $80 \%$ confidence intervals are indicated by dashed lines and show an error of calibration of a factor 1.6 .

From this total only 525 measurements from nine locations were ultimately used for the comparative study between petrography and permeability. This restriction of data was determined by the limited amount of locations from which thin sections could be prepared successfully. Thus, only 25 data points are presented in Table 1, of which anomalous points were eliminated from the subsequent correlation graphs.

Measurements were taken on a grid with a vertical spacing of $1 \mathrm{~cm}$ and a horizontal spacing of $5 \mathrm{~cm}$. Total column height ranged between 10 and $50 \mathrm{~cm}$, and the total number of columns ranged between 6 and 15. On key horizons (e.g. bottomsets) additional rows were measured, with a horizontal and vertical grid distance of $1 \mathrm{~cm}$ (Fig. 2B, E).

The permeability data have been grouped as CFL, FFL and BL data on the basis of sedimentological characteristicsat the points of measurement (Fig. 2E). The resulting three data sets were analysed using standard population statistical techniques. Histograms and cumulative frequency plots were used to characterize the distributions of datasets and subdatasets, from which the optimal a veraging technique was judged.

\section{Petrography}

The cross-bedded sandstone is generally very fine to coarse grained and moderately well sorted (So $=0.6$ 0.9 , Table 1). The grains are usually subangular to subrounded. The framework is composed of three main groups of gains: (I) non-carbonate extrabasinal grains (NCE), (2) carbonate extrabasinal grains (CE) and (3) carbonate intrabasinal grains (CI) (see Table 1).

(1) NCE comprise approximately $75 \%$ of the framework, and are mainly monocrystalline and polycrystalline quartz and K-feldspar. Monocrystalline quartz grains usually show a nonundulatory extinction. The grains are typically irregularly overgrown, and in some cases contain anhydrite inclusions. These features are indicative of provenance from a sedimentary source area (Arribas \& Arribas, 1991). K-feldspar is not abundant (less than $11 \%$, and has inherited overgrowths and filled grain fractures. Partial dissolution of $\mathrm{K}$-feldspar grains is common.

(2) $\mathrm{CE}$ are limestone and dolostone fragments, displaying micritic (CEm) and sparitic (CEsp) textures. CE grains make up $10-35 \%$ of the total rock volume.

(3) $\mathrm{Cl}$ are micritic grains and oncolite fragments. Micritic grains have a homogeneous texture and sometimescontain fragmentsof Characeas sp. and ostracods. In general, they are larger than extrabasinal grains. The intrabasinal clasts were soft and unstable at the time of deposition and often have been deformed by compaction. The percentage of $\mathrm{Cl}$ grains in the framework ranges from 5 to $25 \%$.

The composition of the sandstones is shown in Fig. 4. All plotted points fall in the field in which extrabasinal grains dominate (Fig. 4A). The average composition of these extrabasinal grains is lithoarenitic (Fig. 4B). In agreement with the composition of the sandstone and the sedimentary nature of the rock fragments, the depositsare defined as sedimentoclastic (cf. Ingersoll, 1983). In the NCE-CE-CI diagram (Fig. 4A) samples from each outcrop location form separate clusters, indicating that each sample location has a slightly different bulk composition. In the QFR diagram (Fig. 4B), in which intrabasinal grains are not included, the separation between different outcrops is less clear. The different clusters of data vary 
Table 1. Texture, composition and permeability of analysed sandstones.

\begin{tabular}{|c|c|c|c|c|c|c|c|c|c|c|c|c|c|c|c|c|}
\hline \multirow[t]{2}{*}{ Sample } & \multicolumn{6}{|c|}{ Texture } & \multicolumn{6}{|c|}{ Composition $(\%)$} & \multicolumn{4}{|c|}{ Permeability (D) } \\
\hline & $\begin{array}{c}\text { Average } \\
\text { grainsize } \\
(\phi)\end{array}$ & Sorting & $\begin{array}{c}\text { Primary } \\
\text { porosity } \\
(\%)\end{array}$ & $\begin{array}{c}\text { Secondary } \\
\text { porosity } \\
(\%)\end{array}$ & $\begin{array}{c}\text { Pl } \\
\text { pore size } \\
(\phi)\end{array}$ & $\begin{array}{c}\text { P2 } \\
\text { pore size } \\
(\phi)\end{array}$ & 9 & K-\{eldspar & CEm & CEsp & $\mathrm{Cl}$ & $\begin{array}{c}\text { Carbonate } \\
\text { cement }\end{array}$ & Range & Average & SD & $n$ \\
\hline \multicolumn{17}{|l|}{ CFL } \\
\hline VI. 2 & I. 42 & 0.80 & $21 \cdot 2$ & 10.8 & $2 \cdot 26$ & 110 & $64 \cdot 3$ & $10 \cdot 0$ & $6 \cdot 3$ & $12 \cdot 6$ & $5 \cdot 6$ & 0.9 & $8 \cdot 20-15 \cdot 45$ & $10 \cdot 72$ & 1.77 & 43 \\
\hline IX.I & I.5I & 0.62 & 30.0 & $4 \cdot 6$ & $2 \cdot 26$ & 1.89 & 65.5 & 8.6 & 6.0 & $14 \cdot 3$ & $4 \cdot 0$ & 0.6 & $6.08-11.93$ & 8.49 & 1.56 & 10 \\
\hline IX.2 & $1 \cdot 75$ & 0.81 & $24 \cdot 6$ & $7 \cdot 2$ & $2 \cdot 75$ & $|\cdot 3|$ & 59.6 & 10.3 & $9 \cdot 3$ & 14.9 & 5.6 & 0.0 & $6.80-10.01$ & 8.59 & $1 \cdot 33$ & 7 \\
\hline XII.1 & 1.94 & 0.79 & 25.0 & 6.0 & 2.62 & 1.72 & $56 \cdot 2$ & 5.6 & 6.6 & $21 \cdot 6$ & $8 \cdot 3$ & $1 \cdot 3$ & $2 \cdot 13-6 \cdot 76$ & $4 \cdot 38$ & 1.66 & 4 \\
\hline XIII.2 & 202 & 0.72 & 23.6 & $4 \cdot 2$ & 2.94 & 2.11 & 48.6 & 7.0 & 9.0 & $24 \cdot 2$ & $10 \cdot 3$ & 0.6 & $4 \cdot 11-5 \cdot 52$ & 4.90 & 0.51 & 4 \\
\hline XIV.I & $2 \cdot 32$ & 0.99 & $14 \cdot 8$ & 3.8 & $2 \cdot 74$ & $1 \cdot 18$ & 37.0 & 6.5 & 10.6 & 186 & $25 \cdot 0$ & 0.9 & $7 \cdot 00-15 \cdot 10$ & 10.63 & 2.09 & 14 \\
\hline$X V .1$ & 1.57 & 0.74 & 19.4 & 10.2 & $2 \cdot 46$ & 0.66 & $57 \cdot 1$ & 5.9 & $4 \cdot 3$ & 11.5 & $16 \cdot 8$ & $4 \cdot 2$ & $3 \cdot 41-9 \cdot 83$ & 5.73 & $1 \cdot 39$ & 30 \\
\hline$X V .2$ & 2.69 & 0.69 & 16.4 & 3.4 & 3.62 & $2 \cdot 14$ & 65.6 & 3.6 & $4 \cdot 6$ & 11.6 & $13 \cdot 0$ & $4 \cdot 0$ & $8 \cdot 16-11 \cdot 54$ & 9.97 & $1 \cdot 16$ & 8 \\
\hline XVII.I & $2 \cdot 20$ & 0.82 & $19 \cdot 8$ & $5 \cdot 6$ & $2 \cdot 45$ & $1 \cdot 48$ & 67.9 & $5 \cdot 0$ & 46 & $6 \cdot 3$ & $13 \cdot 3$ & $2 \cdot 6$ & $6 \cdot 12-18.86$ & $12 \cdot 68$ & $3 \cdot 3$ & 28 \\
\hline \multicolumn{17}{|l|}{ FFL } \\
\hline VI.2 & $2 \cdot 35$ & 0.69 & 18.0 & $7 \cdot 2$ & $3 \cdot 22$ & $2 \cdot 01$ & 68.5 & 3.6 & 9.6 & $10 \cdot 3$ & 6.0 & 1.6 & $4.84-9.67$ & 7.07 & $1 \cdot 22$ & 34 \\
\hline IX.I & $2 \cdot 24$ & 0.71 & 244 & 4.8 & $3 \cdot 20$ & $2 \cdot 06$ & 69.6 & 3.0 & $6 \cdot 3$ & 13.0 & $4 \cdot 6$ & $3 \cdot 3$ & $3.81 \cdot-6.43$ & 4.93 & 0.83 & 8 \\
\hline $1 X .2$ & $2 \cdot 67$ & 0.82 & $17 \cdot 8$ & $3 \cdot 2$ & $3 \cdot 34$ & 2.05 & 59.6 & 60 & $10 \cdot 0$ & 10.6 & $10 \cdot 3$ & $3 \cdot 3$ & $4 \cdot 11-6 \cdot 28$ & $5 \cdot 51$ & 0.69 & 7 \\
\hline XII.1 & $2 \cdot 29$ & 0.69 & $22 \cdot 2$ & $5 \cdot 2$ & 3.37 & $2 \cdot 03$ & 626 & $4 \cdot 0$ & $12 \cdot 6$ & 120 & $8 \cdot 3$ & $1 \cdot 3$ & $2 \cdot 77-5 \cdot 10$ & 3.92 & 0.65 & 14 \\
\hline XIII.2 & 3.09 & 0.76 & 215 & 2.9 & 3.84 & $2 \cdot 42$ & 57.6 & $4 \cdot 6$ & 10.6 & $15 \cdot 3$ & $10 \cdot 0$ & 1.6 & $1 \cdot 72-4 \cdot 31$ & 339 & 0.72 & 27 \\
\hline XIV.I & $2 \cdot 54$ & 0.92 & 16.6 & $7 \cdot 0$ & $3 \cdot 30$ & $2 \cdot 40$ & 562 & 3.6 & $11 \cdot 6$ & 7.0 & $19 \cdot 0$ & $2 \cdot 3$ & $2 \cdot 70-8 \cdot 94$ & 6.07 & 2.07 & 28 \\
\hline XVIIII & 2.45 & 0.78 & $19 \cdot 2$ & $8 \cdot 6$ & 3.07 & 2.08 & $56 \cdot 6$ & $4 \cdot 0$ & 1.6 & 6.6 & 18.0 & 3.9 & $2 \cdot 10-12 \cdot 01$ & 5.99 & 2.09 & 55 \\
\hline \multicolumn{17}{|l|}{ BL } \\
\hline VI.2 & $2 \cdot 14$ & 0.67 & $18 \cdot 1$ & 8.7 & $3 \cdot 10$ & 1.79 & 62.5 & 5.6 & $7 \cdot 6$ & 13.6 & $5 \cdot 3$ & 4.9 & $3.01-10.60$ & $7 \cdot 28$ & 1.42 & 36 \\
\hline IX.I & 2.53 & 0.72 & $22 \cdot 2$ & 5.0 & $3 \cdot 30$ & 1.73 & 62.9 & 3.0 & 6.0 & $15 \cdot 3$ & 7.0 & $5 \cdot 6$ & $2.47-5.93$ & 3.74 & 1.04 & 9 \\
\hline XII.I & $2 \cdot 92$ & 0.74 & $21 \cdot 0$ & 58 & 3.50 & 1.44 & $54 \cdot 3$ & 3.6 & 60 & $22 \cdot 0$ & $9 \cdot 6$ & $4 \cdot 3$ & $2 \cdot 15-6.89$ & 3.95 & $1 \cdot 14$ & 26 \\
\hline XIII.2 & 2.97 & 0.71 & $20 \cdot 8$ & 5.4 & 3.60 & 1.83 & 58.9 & $4 \cdot 6$ & $6 \cdot 3$ & 200 & $5 \cdot 6$ & $4 \cdot 3$ & $1.62-595$ & 3.72 & $1 \cdot 25$ & 24 \\
\hline XIV.I & 2.95 & 0.78 & 18.8 & 9.2 & 2.98 & $1 \cdot 17$ & 57.6 & $4 \cdot 0$ & 80 & $15 \cdot 3$ & 7.0 & 8.0 & $1 \cdot 36-10 \cdot 51$ & 6.00 & 1.82 & 43 \\
\hline XV.1-C & $2 \cdot 55$ & 0.95 & 16.8 & $3 \cdot 0$ & $3 \cdot 12$ & 190 & $52 \cdot 3$ & $5 \cdot 3$ & 5.6 & 11.0 & 230 & 1.6 & $2 \cdot 47-5 \cdot 10$ & 3.73 & 0.68 & 26 \\
\hline XV.1-F & $2 \cdot 36$ & 1.05 & 18.2 & 5.4 & $2 \cdot 54$ & 143 & 55.6 & 3.6 & 76 & $14 \cdot 6$ & $15 \cdot 3$ & $2 \cdot 3$ & $1.72-8.03$ & $4 \cdot 77$ & 1.91 & 22 \\
\hline XV.2-C & $2 \cdot 72$ & 0.86 & $20 \cdot 8$ & $4 \cdot 2$ & 2.71 & $2 \cdot 36$ & $51 \cdot 6$ & 5.6 & $5 \cdot 2$ & $11 \cdot 5$ & 247 & $1 \cdot 3$ & $4.09-7.50$ & 6.06 & 1.06 & 8 \\
\hline $\mathrm{XV} \cdot 2 \cdot \mathrm{F}$ & $3 \cdot 26$ & 0.96 & $22 \cdot 6$ & 3.6 & 3.73 & 2.86 & 56.0 & $4 \cdot 0$ & $4 \cdot 0$ & 13.0 & $22 \cdot 0$ & 1.0 & $0.93-5.01$ & 3.84 & 0.85 & 10 \\
\hline
\end{tabular}

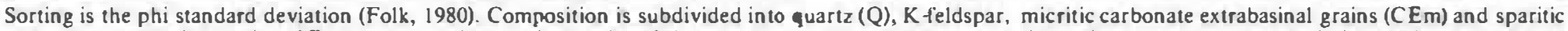

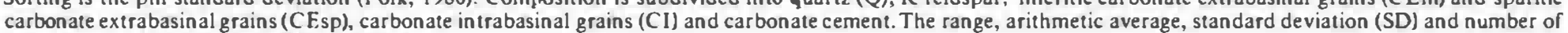
measurements $(n)$ of permeability is presented. 


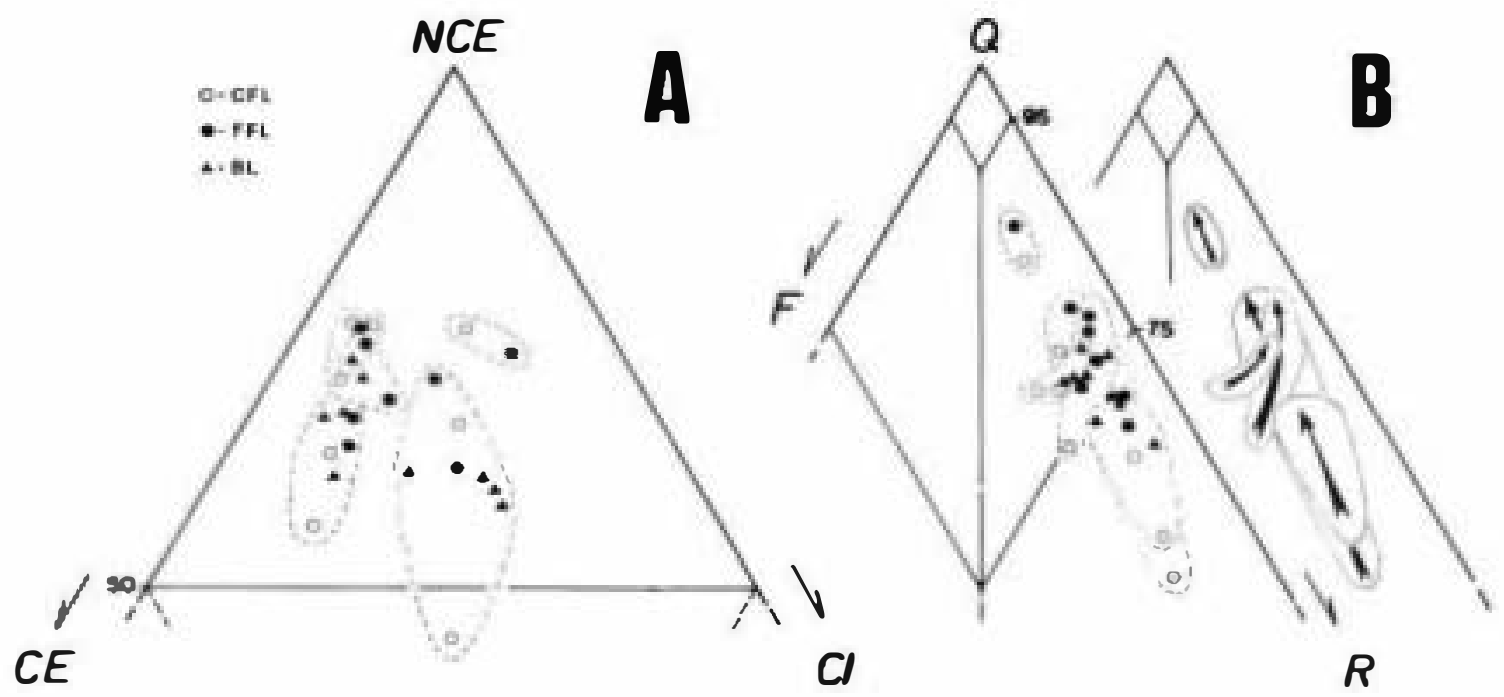

Fig. 4. Framework composition of sandstones: (A) in an NCE-CE-CI diagram (after Zulfa, 1980: (B) in a Q-F-R diagram (after Pettijohn et al., 1973). Samples of a corresponding outcrop location are clustered. Arrows indicate variation in composition from coarser to finer grained subfacies in a cross-bedded set. NCE, non-carbonate extrabasinal; $C E$, carbonate extrabasinal: $\mathrm{Cl}$, carbonate intrabasinal: $\mathrm{Q}$, quartz: $\mathbf{F}$, feldspar: $\mathbf{R}$, rock fragments.

in the ratio between quartz and rock fragments, reflecting small differences in provenance between the various outcrop locations.

Porosity is interpreted to be mainly of primary origin. Primary porosity ranges from 16.4 to $30 \%$ (Table 1). Primary porosity is characterized by interparticle pores, with a poresize distribution closely related to the grain size (Fig. 5). The average primary pore size is approximately $1 \phi$ unit smaller than the average grain size.

\section{Diagenesis}

Diagenesisofthe sandstones includes mechanical and chemical compaction, cementation and generation of secondary porosity. Mechanical compaction mainly affected intrabasinal micritic grains and produced deformed and disintegrated grains. Chemical compaction affected hard micritic grains and some intrabasinal grains (oncolites), which often have concavoconvex contacts with siliciclastic grains, without delormation of internal textures. Cementation has generally not been intense (less than $4 \%$ : Table 1 ) and cements consist mainly of calcite overgrowths around monocrystalline carbonate grains. Locally, equant calcite mosaics are present. From the textural relationship betweendef ormedsoft grains and the undeformed calcite cement, it is concluded that cementation postdatescompaction.

Secondary porosity generation is the last diagenetic process to have affected the sandstones. Secondary porosity is characterized by the presence of oversized

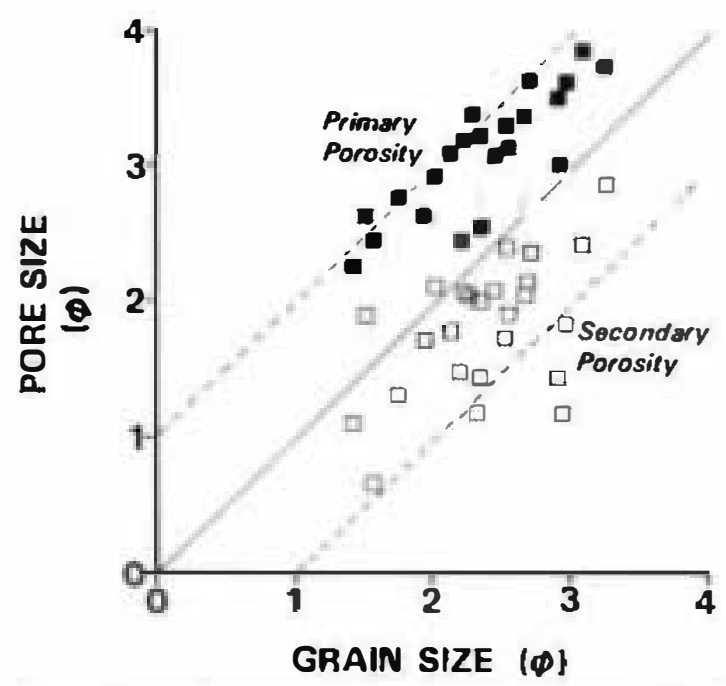

Fig. 5. Average grain size versus average pore size of ( $\square$ ) primary and $(\square)$ secondary porosity. 


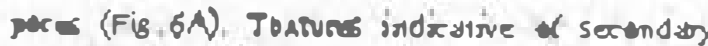

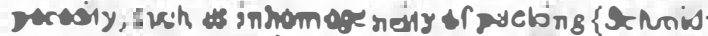

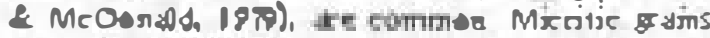

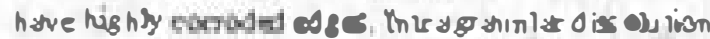

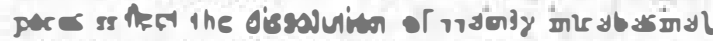

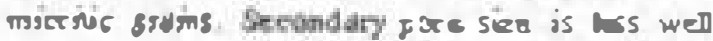

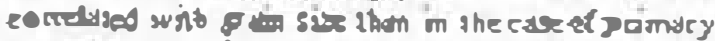

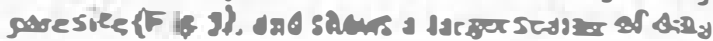

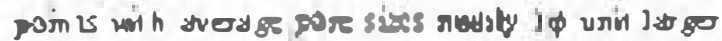

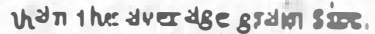

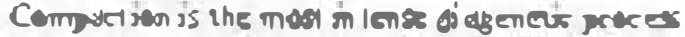

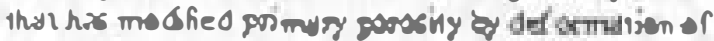

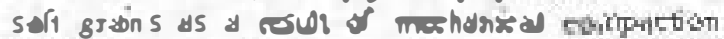

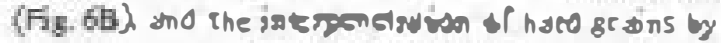

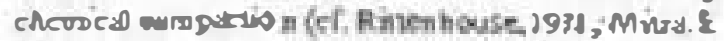

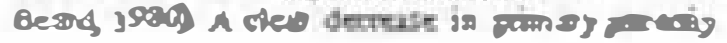
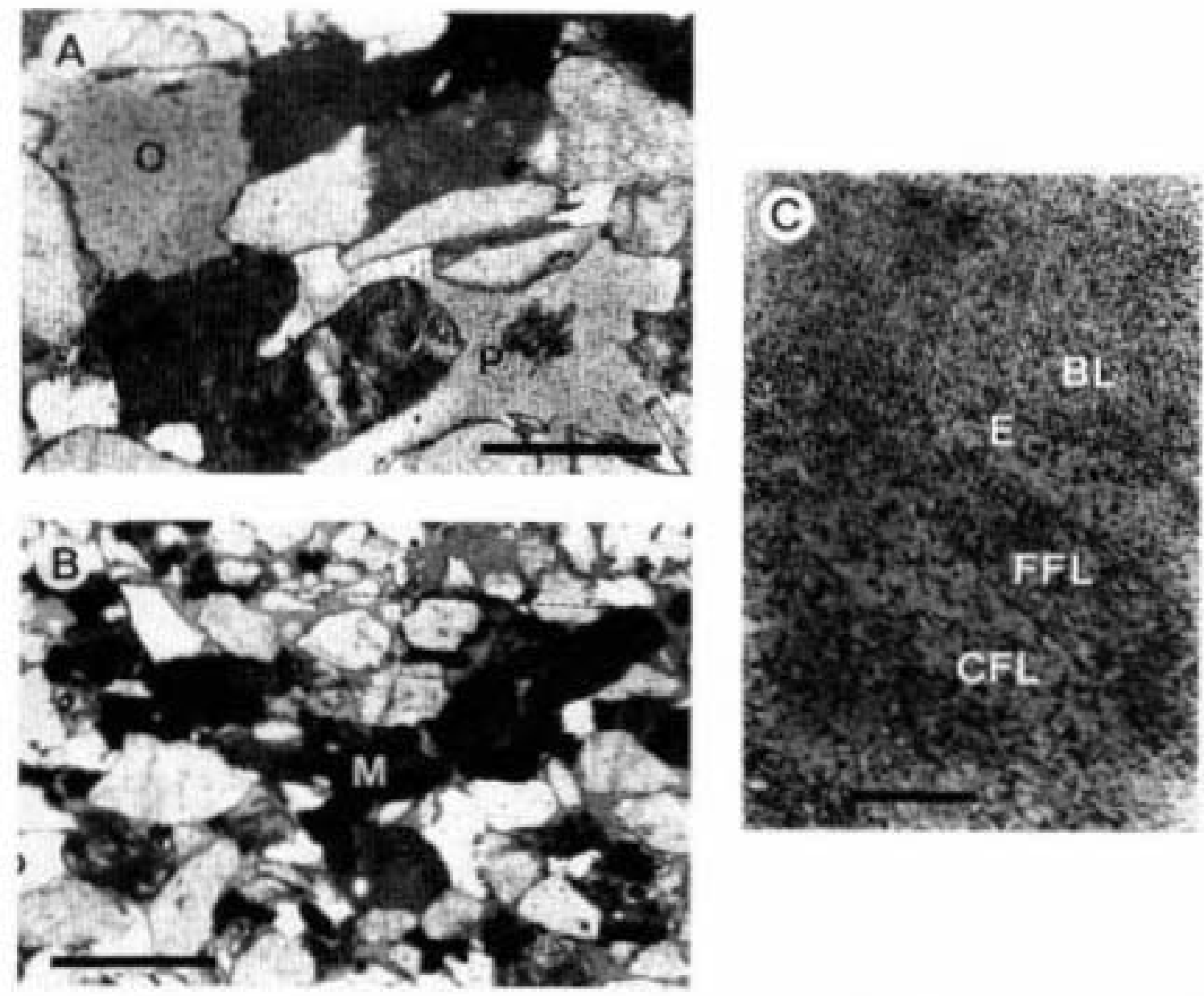

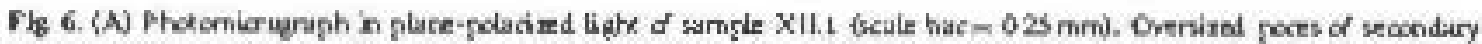

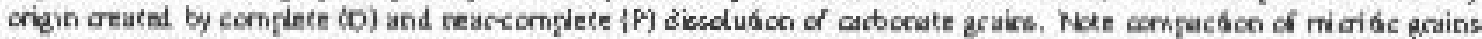

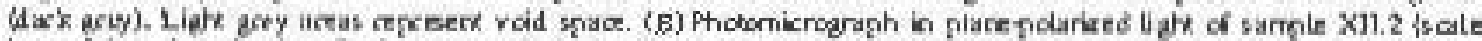

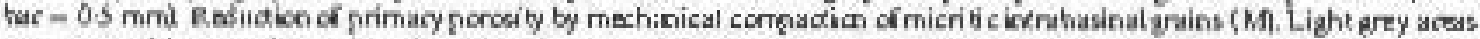

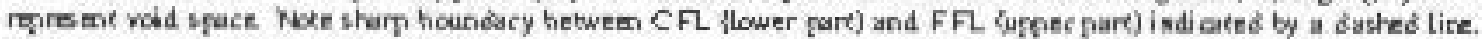

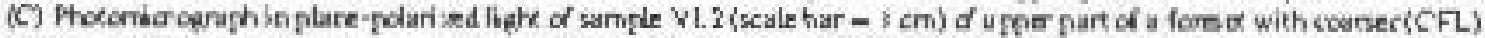

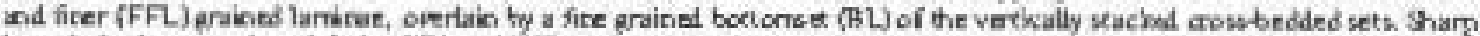

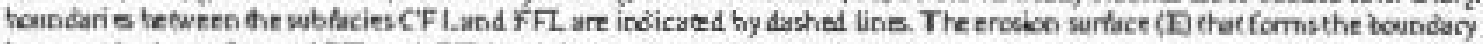
tetween the lower forese (CFL and FFL) and the orelying BL is indicated by a cont cueus sice. 
was found in sandstones with a high percentage of micritic grains (Fig. 7A). This relationship (correlation coefficient $r=-0.555$ ) is obscured by later diagenetic processes such as cementation and secondary porosity generation. It is assumed that secondary porosity merely resulted from dissolution of micritic grains. Thus, by adding the percentage of secondary porosity to the percentage of micritic grains, an estimate of the original micritic grain content is obtained. The percentage of cement, resulting in a reduction of the primary porosity, may be added to the percentage of primary porosity (horizontal axis of the graph), yielding the percentageof pre-cementation porosity (Fig. 7B). Thus, the original porosity of a sandstone with an original framework composition of approximately $40 \%$ carbonate micritic grains is reduced to near $15 \%$ by compactional processes. This fact outlines the relevance of sandstone composition on primary porosity reduction.

\section{Contrasts in petrography}

Boundaries between the different subfacies CFL, FFL and BL are often very sharp (Fig. 6C). It can be
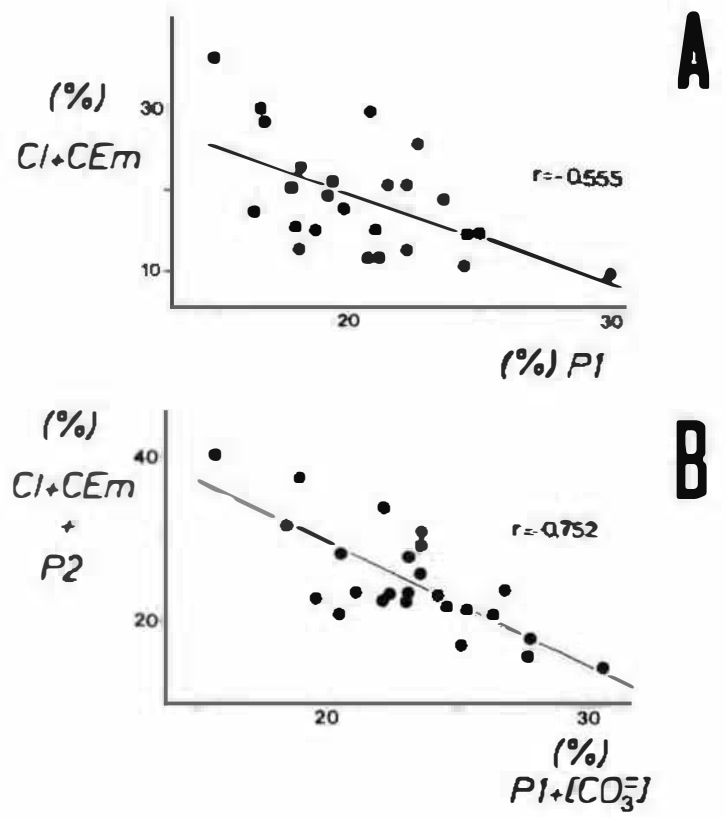

Fig. 7. (A) Percentage of intrabasinal (CI) and extrabasinal carbonate micricic $(\mathrm{CEm})$ grains versus percentage of primary porosity (Pl). (B) Percentage of secondary porosity $(P 2)$ added to $C 1+C E m$ ) versus carbonate cement percentage $\left(\mathrm{CO}_{3}^{2-}\right)$ added to $(\mathrm{Pl})$. observed that the CFL is characteristically coarser grained (medium grained sand) than the FFL and BL (fine grained sand). Sorting of CFL has a wider range (0.62-0.99, well to poorly sorted) than the FFL (069092. moderately to well sorted). The bottomset sands (BL) are generally not as well sorted as the FFL (sorting of BL ranges between 0.67 and 1.05 ). In some cases, bottomsets are better sorted than the foreset laminae. The three subfacies have similar lower limits of primary porosity $(16 \cdot 2-16.8 \%$, thevalueof $14.8 \%$ is considered anomalous ), but differ in their upper limits (CFL : $30 \%$, FFL: $24.4 \%$ and $\mathrm{BL}: 22.2 \%$ ). As pore size (primary and secondary) is directly related to average grain size (see Fig. 5), the pores of CFL are larger than those in FFL and BL.

A significant difference in composition between coarser grained (CFL) and finer grained (FFL + BL) subfacies of individual cross-bedded sets has been observed. The QFR diagram (see Fig. 4B, direction of the arrows) shows that the percentage of quartz grains increases with decreasing grain size. Contrasts in the quantity of micritic grains between the CFL, FFL and BL of individual cross-bed sets result in contrasts of primary porosity evolution and development of secondary porosity between the subfacies (Table 1)

\section{Contrasts in permeability}

The 2600 outcrop probe permeameter measurements range between 0.5 and $20 \mathrm{D}$. In cross-bedded sets where the range in grain sizes is small, the range of permeability is also small. Population statistics prove the independence of the differentsubfacies( $\mathrm{H}$

\& Donselaar. 1993). On the basis of histograms and cumulative frequency plots of permeability data populations and subpopulations (e.g. Fig. 8), the following observations were made. (I) Data populationsshow approximately normal, log-normal or bulk (frequency maximaover several permeability classes) distributions. (2) Subpopulations (i) are in general approximately normally distributed (Gaussian distributions), but log-normal distributions also occur: (ii) foreset data distributions often show two distinct frequency maxima (bimodality according to CFL and FFL data), with a 2-5 D difference;

frequency of bottomset (BL) data often fall in the same class as the lower permeability peak (FFL) of the foreset data distribution (Hartkamp, 1993). From these observations it is concluded that the optimal procedure for calculating the mean of data subpopulations, corresponding to CFL, FFL and $\mathrm{BL}$. is the 

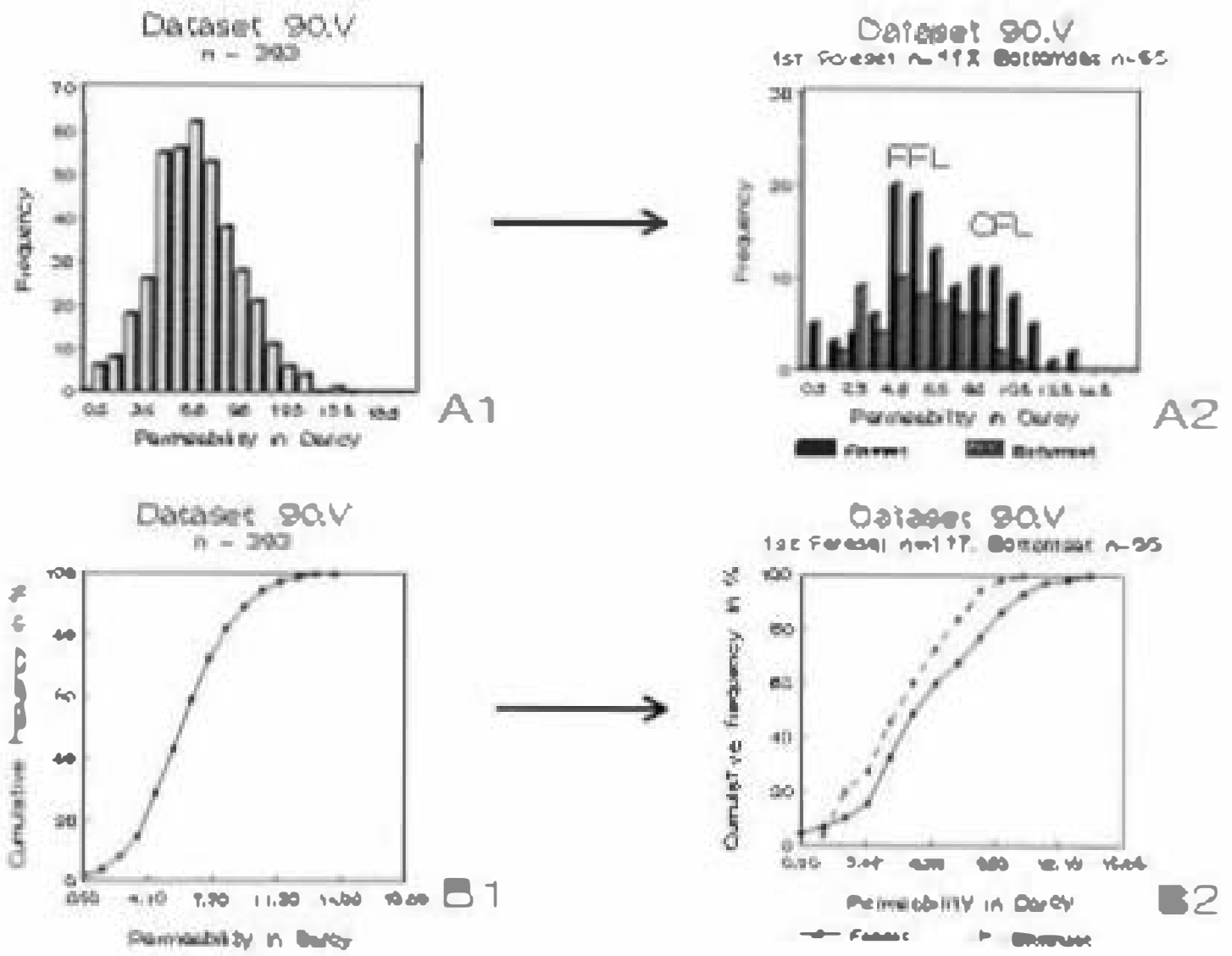

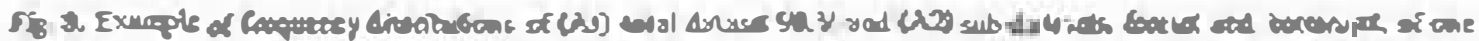

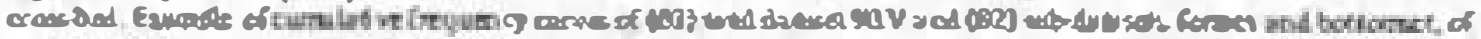

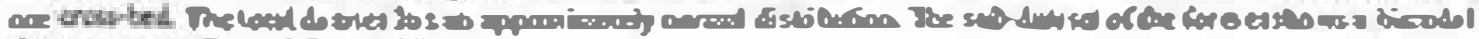

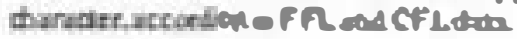

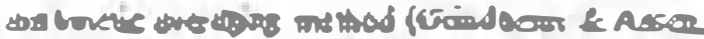

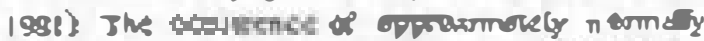

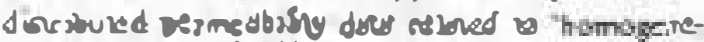

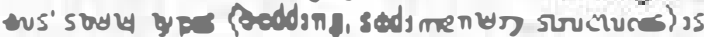
condiamed by olthe sudie ieg Jensen of d. . 1983;

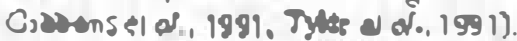

The frequsicy dastivuvers of the daihmouc a veca $3<$ permeos by ofCFL, FFL and $\mathrm{B} L$ daw of all

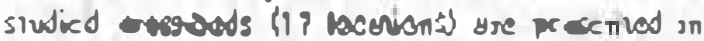

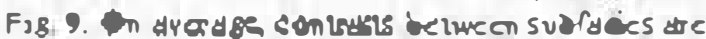

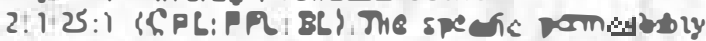
conge, arcoulse and sunderd dev:auens of the

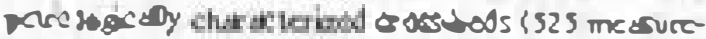

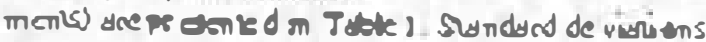

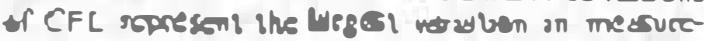

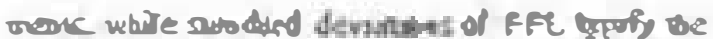
smatss range in measured vatue.

\section{DISCUSSION}

Fecm tyribly in sandrones is in generyl lineaty

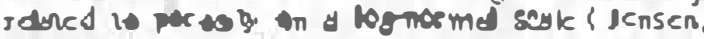
I g्रUג By centrast. in Fag 19 vor wague teands necur

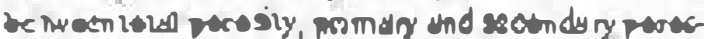
$r y$, ald the por meydjug of ins sudgod sondrenes

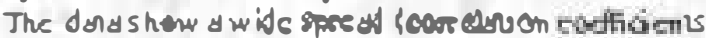

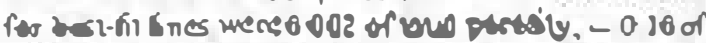

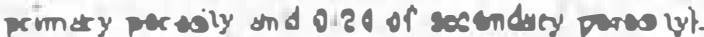

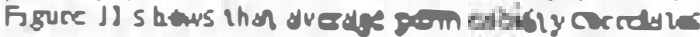




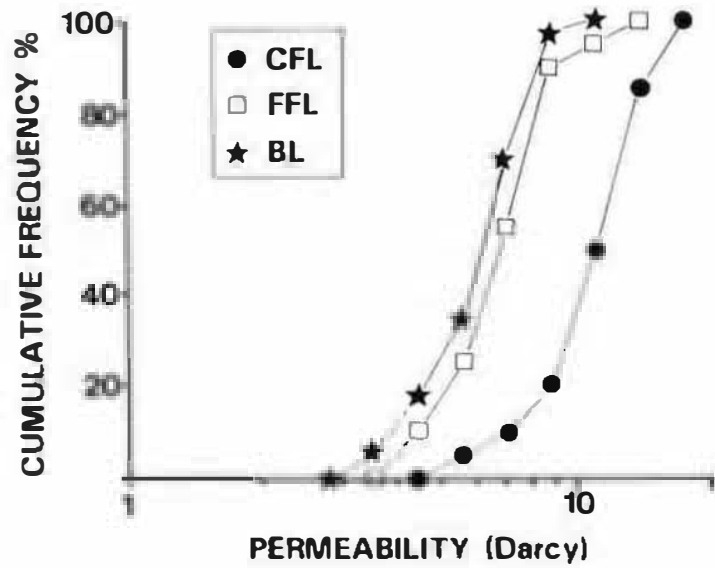

Fig. 9. Cumulative frequency distributions of arithmetic average permeability of CFL, FFL and BL data of all 17 outcrop locations (average permeability of $\mathrm{CFL}=17$. $F F L=17$ and $B L=25$ ). On average. contrasts are $2: 1 \cdot 25: 1$ (CFL:FFL: BL).

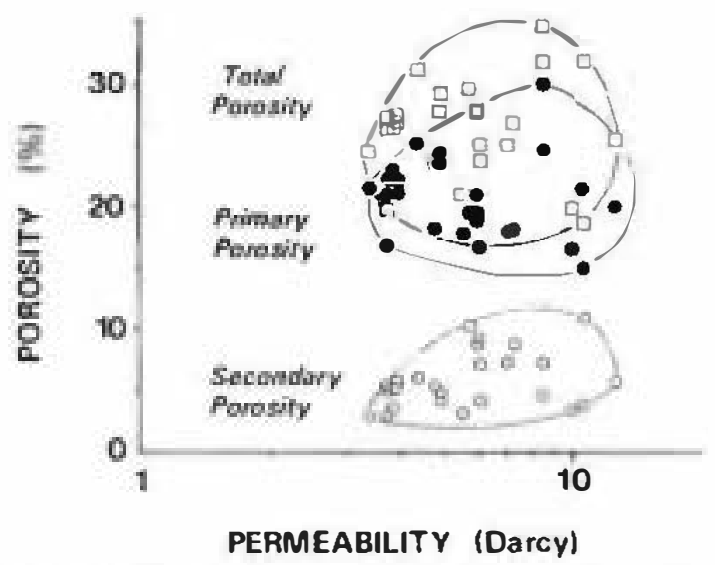

Fig. 10. Primary (O), secondary (O) and total ( $\square$ ) porosity versus permeability.

well with the average pore size of primary pores, although the correlation with the average pore size of secondary pores is less clear. However, permeability clearly decreases with decreasing average pore size. From a compar is onofFigs 10 and 11 it can be in ferred that permeability depends more on average pore size than on total porosity.

To emphasize the effect composition exert on permeability, a graph of perme-

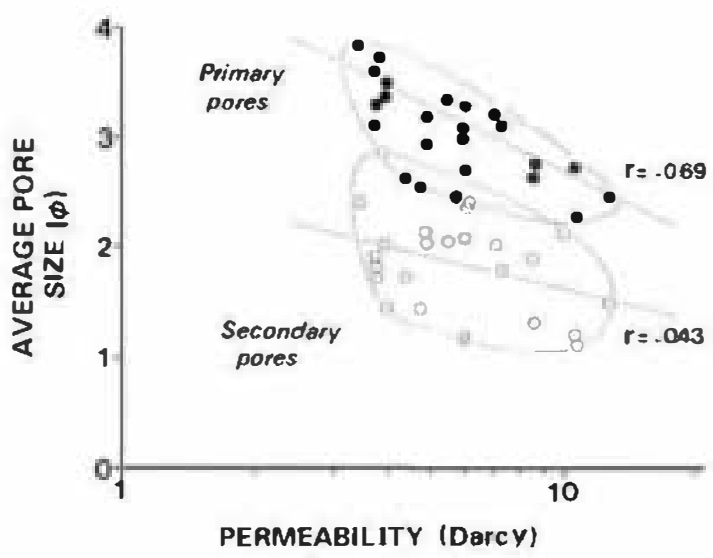

Fig. II. A verage pore size of primary (O) and secondary (O) pores versus permeability.

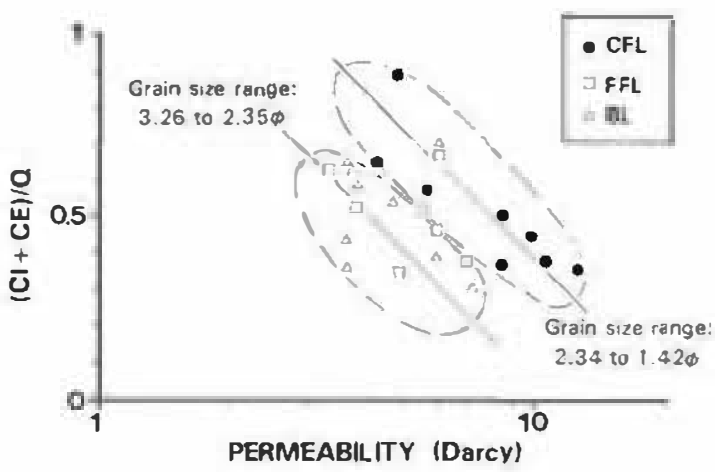

Fig. 12. Sandstone composition $[(\mathrm{Cl}+\mathrm{CF}) / \mathrm{Q}$ index $]$ versus permeability with samples grouped as a function of grain size. Note the relevance of provenance (sandstone composi(ion) and grain size on permeability. Cl. carbonate intrabasinal. CE. carbonatcextrabasinal; Q. Quartz.

ability versus composition (ratio of carbonate to quartz grains) is presented in Fig. 12. The different grain sizes are refiected in the separation of the generally coarser grained CFL and the generally finer grained FFL and BL. For both clusters a clear correlation exists between a

carbonate to quartz with increasing permeability. Figure 12 shows that permeability depends primarily on: (1) mineralogical composition and related diagenetic processes ( $y=a x i s)$ and (2) the grain size. 


\section{CONCL USIONS}

1. In the cross-beds, average grain sizes range from medium grained sand in the coarser grained foreset laminae (CFL) to fine grained sand in the finer grained foreset laminae (FFL) and bottomset (BL). The sand is on average moderately well sorted $(S o=0.6-0.9)$.

2. The average size of primary pores is approximately $1 \phi$ unit smaller than the average size of the poreforming grains. The secondary pores (oversized pores) are approximatelyh $I \phi$ unit larger than the average grain size.

3. The differences in framework compositionbetween the different outcrop locations are a result of small differences in provenance. Compositional contrasts between the subf acies of a cross-bedded set are related to grain size. Coarser grained foreset laminae (CFL) have a larger amount of carbonate intra- and extrabasinal grains than do the adjacent finer grained laminae (FFL) and bottomsets (BL).

4. The abundance of micritic grains is decisive in the course of diagenesis, controlling the primary porosity reduction by compaction and secondary porosity generation. Contrasts in the quantity of micritic grains between the CFL, FFL and BL of individual crossbed sets result in contrasts of primary porosity evolution and development of secondary porosity between the subfacies. A correlation exists between a decreasing ratio of carbonate to quartz and increasing permeability.

5. Outcrop probe permeameter studies show a range in permeabilities of 0.5-20 D. On average, contrasts in permeability between the subfacies are $2: 1.25: 1$ (CFL:FFL:BL).

6. Probe permeability contrasts between CFL, FFL and $B L$ depend on pore size and mineralogical composition contrasts between the subf acies.

\section{ACKNOWLEDGMENTS}

Thanks are due to Margarita Diaz Molina of the Universidad Complutense in Madrid for her valuable discussions in the field and for her constructive comments on the manuscript. Professor K. J. Weber is kindly thanked for his critical reading of the typescript and encouragement. The helpful comments of Thea van de Graalf-Trouwborst and Evert van de Graaff were much appreciated. Sedimentology reviewers Andrew Hurst and Steve Ehrenberg are thanked for criticial comments on the typescript. Suggestions from an anonymous referee were also appreciated.
Arribas, J. \& Arribas, M.E. (1991) Petrographic evidence of different provenance in two alluvial fan systems (Paleogene of the Northem Tajo Basin, Spain). In: Developments in Sedimentary Provenance Studies (Ed. by A. C. Morton, S. P. Todd \& P. D. W. Haughton), Spec: Publ.geol. Soc., 57, 263-27I.

VAN BAAREN, J.P. (1979) Quick-look permeability estima tes using sidewall samples and porosity logs. In: Proc S.P.W.L.A. 6th European Logging Conference, London, March, pp. $1-11$.

BEARD, D.C. \& WEYL, P.K. (1973) Influence of tex lure on porosity and permeability of unconsolidated sand. Bull. Am. Ass. petrol. Geol. 57, 349-369.

Carman, P.C. (1937) Fluid flow through granular beds. In: Trans. Inss. Chem. Eng., 15. I 50-166.

Chandler, M.A., Kocurek, G., Goggin, D.J. \& Lake, L.W. (1989) Effects of stratification heterogeneity on permeabiality in eolian sandstone sequence, Page Sandstone, Northern Arizoni. Bull. Am. Ass. perrol. Geol., 55, 307-309.

Diaz Molina, M., Arribas Mocoroa, J. \& Bustillo Revuelta, A. (1989) The Tórtola and Villal ba de la Sierra fiuvial fans: late Oligocene-Early Miocene, Loranca Basin, Central Spa in. In : Guidebook for Fielderip 7, 4i h / $\mathrm{mt}$. Conf. on Flurial Sedimentology, Barcelona-Sitges,

(Ed. by C. Puigdefabregas). Servei Geologicde Ca ta lun ya.

Diaz Molina, M.. Capote, R. \& Lopez Martinez, N. (1985) Wet fluvial fans of the Loranca Basin (Central Spain), channel models and distal bioturbated gypsum and chert. In: Fieldtrip Gudebook, 6th Ine. Ass. Sediment., Eur. Reg. Meeting, Lerida, Spain (Ed. by M. D. Mila \& J. Rossell), Pp. 149-185. Institut d'estudis Illerdencs.

Dreyer. T., SChrele, A \& Walderhaug, O. (1990) Minipermea meter-based study of permeability trends in channel sand bodies. Bull. Am. Ass. petrol. Geol., 74, 359-374.

EHRENBERG, S.N. (1990) Relationship between diagenesis and Reservoir Quality in sandstones of the Garn Formation. Halterbanken, mid-norwegian continen ta lshe r. Bull. Am. Ass. peirol. Geol., 74, 1538-1558.

EIJPE, R. \& WEBER, K.J. (1971) Minipermeameters for conso lida ted rock and unconsolidated sand. Bull. Am. Ass. perrol. Geol., 55, 307-309.

Folk, R.L. (1980) Perrologyof Sedimenary Rocks. He mphill Publishing Company, Austin, TX.

Gibbons, K., Halvorsen, C. \& Siring, E. (1991) Vertical and horizontal penneability variation within a sandstone reservoir based on minipenneameter data. In: Proc. Ist Minipermearry in Reserv. Studies Conference, Edin burgh, 27-28 June, Pp. 1-9.

Goggin, D.J., Thrasher, R.L. \& Lake, L.W. (1988) A theore tical and experimen tal analysis of minipermeame te $r$ response including gas slippage and high velocity flow effects. In Siru, 12, 79-116.

Grindheim, A.O. \& AASEN. J.O. (1991) All Evaluation of Homogenization Techniques for Absoluse Permeability. Lerkendal Petroleum Engineering Workshop, Trondheim.

Halvorsen, C. \& Hurst, A. (1990) Principles. practice and application sof labora tory min ipermeametry. In : Aduances in Core Elaluotion. Accuracy and Precision in Reserves Estimation (Ed. by P. F. Worthingt on, pp. 521-549. Gordon \& Breach. 
HaRTK AMP, C.A. (1993) Permeahility heterogeneity in cras:heddedsandstones. Impact on water joil displacement influvial resertoirs. PhD thesis. Krips-Repro. Meppel (in press).

HartK amp, C.A. \& Donselaar, M.E. (1993) Permeability patterns in point-bar deposits: Tertiary Loranca Basin, CentralSpain. In: TheGeologicul Modellingo III ldrocartion Resernoirs (Ed. by S. Flint \& I. Bryant), Spec. Publs Int. Ass. Sediment., 15, 157-168.

Hopkins, J.C.. WOOD, J.M. \& KRALISE, F.F. (1991) Waterflood response of reservoirs in an estuarine valley fill: Upper Manville, G. $U$ and $W$ Pools, Little Bow Field. Alberta. Canadd. Bull. Am. Ass. petrol. Geol, 75, 10641088.

Hurst, A. \& Rosvoli, K. (1991) Permeability varialions in sandstones and their relationship to sedimentary structures. In: Reservoir Characterisation // (Ed. L. W. Lake, H. B. Carroll, Jr \& T. C. Wesson), pp. I 16-196. Academic Press, San Diego, CA.

I NGERSOLL, R.V. (1983) Petrof acies and provenance of a late Mesozoic forearc basin, northern and central Californid. Bull. Am. Ass. petrol. Geol., 67, $1125-1142$.

JENSEN, J.I.. (1990) A model for small-scale permeability measurement with applications to reservoir characterization. In: Proc. Soc. Petrol. Engineers S.mposium on Enhanced Oil Recoler;: Tulsa, OK, SPE 20265, 891-900.

Jensen, L.J., HINkLEY, D.V. \& IAKE, L.W. (1987) A statistical study of reservoir permeability: Distributions. correlations and averages. Soc. Petrol. Eng. Form. Eval., December, 461-468.

JOPLIN, A.V. (1965) Laboratory study of the distribution of grain sizes in cress-bedded deposits. In: Primary Sedimentary Siruchures and Their Hydrod ynamic Interpretation (Ed. by G. V. Middleton), Spec. Publ. Soc. Econ. puleont. Miner., 12. 53-65.
KOZENY, J. (1927) Uber kapillare leitung des wassers in boden. Sizher Akad. Wiss. Wien, Math. Naturu. Klasise, Ab1. I/A, 136, 271-306.

MITRA, S. \& BEARD, W.E. (1980) Theoretical models of porosity reduction by pressure solution for well-sorted sandstones. I. seilim. Petrol., SO, I347-1360.

Pettijohn, F.J., Potier. P.E. \& Siever, R. (1973) Sand and Sumlstone. Springer-Verlag, New York.

PIttman, E.D. (1979) Porosity, diagenesis and productive capabilit y of sandstone reservoirs. In: Aspectsof Diagenesis (Ed. by P. A. Scholle \& P. R Schluger. Spec. Puthl. Soc. Econ. paleont. Miner. 26, 159-173

RITTENhouse, G. (1971) Mechancial compaction of sands containing different percentages of ductile grains: a theoretical approach. Bull. Am. As.s. petrol. Geol., 55, 9296.

Schmidt, V. \& McDonald, D.A. (1979) The role of secondary porosity in the course of sandstone diagenesis. In: Aspects of Diagenesis (Ed. by P. A. Scholle \& P. R. Schluger), Spec. Puhl. Soc. Econ. paleont. Miner. 26. 17.5207.

Suitherland, W.I., Halvorsen, C., Hurst, A. McPhee, C.A., RobertSON, G., WhatILER,P.R.\& WORIHINGTON, P.F. (1991) Recommended practice for probe permeametry. In: Proc: Minipermeatry in Reseru. Sudies Conference, Edinburgh, 27-28 June, pp. 1-26.

Trler, N., Barton, M.D. \& Finley, R.J. (1991) Outcrop characterization of flow unit and seal properties and geometries. Ferron Sandsione, Uiah. In: Proc. 66th Soc. Petrol. Enginecrs Annual Technical Conference and Exhibitions, Dallas, 6-9 October, SPE 22670, 127-134.

ZuFfa, G.G. (1980) Hydrid arenites: their composition and clissilication. I. sedim. Petrol, 50, 21-29 